\title{
Transition of antibody titers after the SARS-CoV-2 mRNA vaccine in Japanese healthcare workers
}

Masahiro Kitabatake $\mathrm{PhD}^{1}$, Noriko Ouji-Sageshima $\mathrm{PhD}^{1}$, Shota Sonobe $\mathrm{MD}^{1,2}$, Ryutaro Furukawa MD PhD ${ }^{1,3}$, Makiko Konda $\mathrm{MD}^{1,2}$, Atsushi Hara BS ${ }^{1}$, Hiroyasu Aoki BS ${ }^{4}$, Yuki Suzuki $\mathrm{PhD}^{5}$, Natsuko Imakita $\mathrm{MD} \mathrm{PhD}^{3}$, Akiyo Nakano $\mathrm{PhD}^{5}$, Yukio Fujita $\mathrm{MD} \mathrm{PhD}^{6}$, Shigeyuki Shichino $\mathrm{PhD}^{4}$, Ryuichi Nakano $\mathrm{PhD}^{5}$, Satoshi Ueha $\mathrm{PhD}^{4}$, Kei Kasahara MD $\mathrm{PhD}^{3}$, Shigeo Muro MD $\mathrm{PhD}^{6}$, Hisakazu Yano $\mathrm{MD} \mathrm{PhD}^{5}$, Kouji Matsushima MD $\mathrm{PhD}^{4}$, Toshihiro Ito $\mathrm{MD}, \mathrm{PhD}^{1 *}$

${ }^{1}$ Department of Immunology, Nara Medical University, Nara, Japan.

${ }^{2}$ Department of Anesthesiology, Nara Medical University, Nara, Japan.

${ }^{3}$ Center for Infectious Diseases, Nara Medical University, Nara, Japan.

${ }^{4}$ Division of Molecular Regulation of Inflammatory and Immune Diseases, Research Institute for Biomedical Sciences, Tokyo University of Science, Chiba, Japan.

${ }^{5}$ Department of Microbiology and Infectious Diseases, Nara Medical University, Nara, Japan.

${ }^{6}$ Department of Respiratory Medicine, Nara Medical University, Nara, Japan.

\section{*Corresponding author}

Toshihiro Ito, $\mathrm{MD}, \mathrm{PhD}$

Department of Immunology, Nara Medical University

840 Shijo-cho, Kashihara, Nara 634-8521, Japan

toshi-ito@naramed-u.ac.jp

$+81-744-22-3051$

Keywords: SARS-CoV-2, COVID-19, mRNA vaccine, neutralizing antibody titer, virus infectivity titer, spike protein, receptor-binding domain 
medRxiv preprint doi: https://doi.org/10.1101/2021.12.28.21268435; this version posted December 31, 2021. The copyright holder for this

preprint (which was not certified by peer review) is the author/funder, who has granted medRxiv a license to display the preprint in

All rights reserved. No reuse allowed without permission.

\begin{abstract}
Since February 2021, health care workers in Japan have been preferentially vaccinated with a messenger RNA vaccine (BNT162b2/Pfizer) against severe acute respiratory syndrome coronavirus 2 (SARS-CoV-2). While many studies have confirmed that this vaccine is highly effective in reducing hospitalizations and deaths from coronavirus disease 2019 (COVID-19), antibody titers tend to decline at 3 months, leading to a risk of breakthrough infections. Thus, information is needed to support decision making regarding the third vaccination. In this study, we investigated transition of the anti-SARSCoV-2 receptor-binding domain (RBD) IgG and neutralizing antibody titers of 41 vaccinated Japanese healthcare workers. Samples were collected seven times starting 1 week before vaccination until 6 months post-vaccination. Anti-SARS-CoV-2 RBD IgG levels peaked at 7 days after the booster, then declined over time and decreased to $<10 \%$ at 6 months after the booster. Workers with low anti-SARS-CoV-2 RBD IgG levels also had low neutralizing antibody titers. These data support the active use of boosters for healthcare workers, especially for those with low anti-SARS-CoV-2 RBD IgG levels.
\end{abstract}

\title{
Introduction
}

The efficacy and safety of the BNT162b2 mRNA coronavirus disease 2019 (COVID-19) vaccine (Pfizer-BioNTech, Mainz, Germany) has been widely demonstrated ${ }^{1}$. Real-world data on BNT162b2 have confirmed that this vaccine is highly effective in reducing laboratory-confirmed and community-acquired infections, viral loads in infected individuals, and COVID-19-related hospitalizations and deaths ${ }^{2,3}$. However, breakthrough infections have been reported in fully vaccinated persons ${ }^{4}$. Healthcare workers are potentially at a higher risk of infection owing to prolonged and repeated exposure to severe acute respiratory syndrome coronavirus 2 (SARS-CoV-2)-infected patients $^{5}$. A recent study reported that among fully vaccinated health care workers, the occurrence of SARS-CoV-2 breakthrough infections was correlated with neutralizing antibody titers during the peri-infection period ${ }^{3}$. Another study found that patients' humoral responses were substantially decreased 6 months after receiving the second dose of the BNT162b2 vaccine ${ }^{6}$. In this study, we evaluated the transition of antibody titers from the SARS-CoV-2 mRNA vaccine in 41 Japanese healthcare workers and the relationship between anti-SARS-CoV-2 receptor-binding domain (RBD) IgG levels and neutralizing antibody titers 6 months after the workers received the second BNT162b2 vaccine. 
medRxiv preprint doi: https://doi.org/10.1101/2021.12.28.21268435; this version posted December 31, 2021. The copyright holder for this

preprint (which was not certified by peer review) is the author/funder, who has granted medRxiv a license to display the preprint in

All rights reserved. No reuse allowed without permission.

\section{Methods}

Forty-one healthcare workers at Nara Medical University in Japan who had received the Pfizer-BNT162b2 vaccine between 10 March and 30 March 2021 were invited to participate as volunteers in the study. Participants provided peripheral blood samples for serologic assays before receiving the first vaccine, 1 week after receiving the first vaccine, then 1 week, 1 month, 3 months, and 6 months after receiving the second vaccine. All study participants provided written informed consent. Eligibility criteria were that participants were $\geq 20$ years of age and had no history of suspected clinical SARS-CoV-2 infection. The Nara Medical University Ethics Committee approved the study (No. 3168).

All serum samples from vaccinated participants were tested for antibodies against the SARS-CoV-2 spike protein RBD with a COVID-19 human IgG enzyme-linked immunosorbent assay kit per the manufacturer's instructions (RayBiotech Life, Inc. Peachtree Corners, GA, USA). The SARS-CoV-2 virus neutralization assay was performed as described previously ${ }^{7}$. SARS-CoV-2 (nCoV-19/JPN/TY/WK521/2020) was isolated and provided from the National Institute of Infectious Diseases, Japan. Serial 2fold dilutions of heat-inactivated sera were incubated with equal volumes of 200 plaqueforming units of SARS-CoV-2 at $37^{\circ} \mathrm{C}$ for $1 \mathrm{~h}$. VERO E6/TMPRSS2 cells (JCRB Cell Bank, Japan, JCRB1819) were infected with half the volume of the virus-serum mixture for $1 \mathrm{~h}$, then covered with agarose overlay. After $48 \mathrm{~h}$ of incubation, cells were fixed and inactivated with $10 \%$ formalin, then the agarose overlay was removed, and the cells were stained with crystal violet. The visible plaques were counted, then $50 \%$ plaque-reduction neutralization tests were used to determine the titers as the maximum serum dilution that reduced the plaque number by $>50 \%$. All experiments using SARS-CoV-2 were performed in a biosafety level 3 facility at Nara Medical University, Japan.

\section{Results}

We investigated the transition of anti-SARS-CoV-2 RBD IgG levels during the 6-month follow-up. The RBD IgG levels were slightly increased 7 days after participants received the first dose of the Pfizer-BNT162b2 vaccine (43.8 binding antibody units (BAU) /ml, 95\% confidence interval $[\mathrm{CI}]: 15.3-125.4)$ compared with those before the vaccination (10.3 BAU/ml, 95\% CI: 3.5-29.9). The highest titers were observed 7 days after the second dose of the Pfizer-BNT162b2 vaccine (4549 BAU/ml, 95\% CI: 3604-5740), then 
medRxiv preprint doi: https://doi.org/10.1101/2021.12.28.21268435; this version posted December 31, 2021. The copyright holder for this

preprint (which was not certified by peer review) is the author/funder, who has granted medRxiv a license to display the preprint in

All rights reserved. No reuse allowed without permission.

the titers decreased by factors of 3.4 after 1 month (1341 BAU/ml, 95\% CI: 1077-1671), 6.6 after 3 months (684.2 BAU/ml, 95\% CI: 552.8-895.5), and 15.3 after 6 months (297.3 BAU/ml, 95\% CI: 217.5-406.3).

Next, to investigate whether the anti-SARS-CoV-2 RBD IgG levels were correlated with the neutralizing antibody levels, we examined the neutralizing antibody values, expressed as $50 \%$ neutralizing titers, from the highest eight and lowest eight SARS-CoV-2 RBD IgG levels from participants 6 months after the second vaccination. The anti-SARS-CoV2 RBD IgG levels were positively correlated with the neutralizing antibody levels, and low SARS-CoV-2 RBD IgG levels indicated very low or undetectable neutralizing antibody levels.

\section{Discussion}

Studies are ongoing regarding SARS-CoV-2, long-term vaccine effectiveness, breakthrough infections, and effectiveness of the vaccine against mutant strains after the second dose of the BNT162b2/Pfizer vaccine. Our results indicated that BNT162b2 boosters generated large antibody responses in Japanese healthcare workers, but the antiSARS-CoV-2 antibody titers decreased to approximately $1 / 15$ at 6 months after the second vaccination. Low serum SARS-CoV-2 RBD IgG levels were strongly correlated with low neutralizing antibody levels against SARS-CoV-2. Healthcare workers are at a higher risk for SARS-CoV-2 infection, and the SARS-CoV-2 infection rate in healthcare workers reportedly varies between $3 \%$ and $17 \%$ according to the history, degree of exposure and presence of symptoms ${ }^{8}$. Therefore, in Japan, the BNT162b2 vaccination was recommended for healthcare workers in advance because of its high effectiveness in preventing confirmed infections, critical disease, and death. A recent study demonstrated substantially decreased humoral immunity against SARS-CoV-2 at 6 months after receiving the second dose of the BNT162b2 vaccine ${ }^{6}$. These data suggest that the booster should be highly recommended for healthcare workers, especially those with low serum SARS-CoV-2 RBD IgG levels 6 months after the second dose. Additionally, some reports indicate lower effectiveness against mutant SARS-CoV-2 strains, such as delta and omicron $^{9,10}$.

This study had some limitations, including a small sample size, no use of mutant strains in the neutralization responses, and an absence of cellular immune responses. Additionally, other than for the humoral response, data are lacking regarding cell- 
medRxiv preprint doi: https://doi.org/10.1101/2021.12.28.21268435; this version posted December 31, 2021. The copyright holder for this preprint (which was not certified by peer review) is the author/funder, who has granted medRxiv a license to display the preprint in All rights reserved. No reuse allowed without permission.

mediated immune responses and to what extent this protection contributes to the longterm efficacy of the vaccine. Therefore, the effects of long-term transition and boosters on cell-mediated immunity should be investigated in detail.

\section{Acknowledgments}

We thank Ms. Hisayo Nishikawa (Department of Immunology, Nara Medical University), for their assistance. We also thank Traci Raley, MS, ELS, from Edanz (https://jp.edanz.com/ac) for editing a draft of this manuscript.

\section{Conflicts of Interest}

All authors declare no conflicts of interest. 


\section{References}

1. Abu-Raddad LJ, Chemaitelly H, Butt AA; National Study Group for COVID-19 Vaccination. Effectiveness of the BNT162b2 Covid-19 Vaccine against the B.1.1.7 and B.1.351 Variants. $N$ Engl $J$ Med. 2021 Jul 8;385(2):187-189. doi: 10.1056/NEJMc2104974.

2. Dagan N, Barda N, Kepten E, Miron O, Perchik S, Katz MA, Hernán MA, Lipsitch M, Reis B, Balicer RD. BNT162b2 mRNA Covid-19 Vaccine in a Nationwide Mass Vaccination Setting. New Engl J Med. 2021 Apr 15;384(15):1412-1423. doi: 10.1056/NEJMoa2101765.

3. Bayart JL, Douxfils J, Gillot C, David C, Mullier F, Elsen M, Eucher C, Van Eeckhoudt S, Roy T, Gerin V, Wieers G, Laurent C, Closset M, Dogné JM, Favresse J. Waning of IgG, Total and Neutralizing Antibodies 6 Months Post-Vaccination with BNT162b2 in Healthcare Workers. Vaccines (Basel). 2021 Sep 28;9(10):1092. doi: 10.3390/vaccines9101092.

4. Bergwerk M, Gonen T, Lustig Y, Amit S, Lipsitch M, Cohen C, Mandelboim M, Levin EG, Rubin C, Indenbaum V, Tal I, Zavitan M, Zuckerman N, Bar-Chaim A, Kreiss Y, Regev-Yochay G. Covid-19 Breakthrough Infections in Vaccinated Health Care Workers. $N$ Engl $J$ Med. 2021 Oct 14;385(16):1474-1484. doi: 10.1056/NEJMoa2109072.

5. Alishaq M, Nafady-Hego H, Jeremijenko A, Al Ajmi JA, Elgendy M, Vinoy S, Fareh SB, Veronica Plaatjies J, Nooh M, Alanzi N, Kaleeckal AH, Latif AN, Coyle P, Elgendy $\mathrm{H}$, Abou-Samra AB, Butt AA. Risk factors for breakthrough SARS-CoV-2 infection in vaccinated healthcare workers. PLoS One. 2021 Oct 15;16(10):e0258820. doi: 10.1371/journal.pone.0258820.

6. Levin EG, Lustig Y, Cohen C, Fluss R, Indenbaum V, Amit S, Doolman R, Asraf K, Mendelson E, Ziv A, Rubin C, Freedman L, Kreiss Y, Regev-Yochay G. Waning Immune Humoral Response to BNT162b2 Covid-19 Vaccine over 6 Months. N Engl J Med. 2021 Dec 9;385(24):e84. doi: 10.1056/NEJMoa2114583.

7. Kitabatake M, Inoue S, Yasui F, Yokochi S, Arai M, Morita K, Shida H, Kidokoro M, Murai F, Le MQ, Mizuno K, Matsushima K, Kohara M. SARS-CoV spike proteinexpressing recombinant vaccinia virus efficiently induces neutralizing antibodies in rabbits pre-immunized with vaccinia virus. Vaccine. 2007 Jan 8;25(4):630-7. doi: 10.1016/j.vaccine.2006.08.039.

8. Alajmi J, Jeremijenko AM, Abraham JC, Alishaq M, Concepcion EG, Butt AA, Abou-Samra AB. COVID-19 infection among healthcare workers in a national 
medRxiv preprint doi: https://doi.org/10.1101/2021.12.28.21268435; this version posted December 31, 2021. The copyright holder for this preprint (which was not certified by peer review) is the author/funder, who has granted medRxiv a license to display the preprint in All rights reserved. No reuse allowed without permission.

healthcare system: The Qatar experience. Int J Infect Dis. 2020 Nov;100:386-389. doi: 10.1016/j.ijid.2020.09.027.

9. Demonbreun AR, Sancilio A, Vaught LA, Reiser NL, Pesce L, McNally EM, McDade TW. Antibody titers before and after booster doses of SARS-CoV-2 mRNA vaccines in healthy adults. medRxiv 2021.11.19.21266555; doi: https://doi.org/10.1101/2021.11.19.21266555

10. Lu L, Mok BW, Chen LL, Chan JM, Tsang OT, Lam BH, Chuang VW, Chu AW, Chan WM, Ip JD, Chan BP, Zhang R, Yip CC, Cheng VC, Chan KH, Jin DY, Hung IF, Yuen KY, Chen H, To KK. Neutralization of SARS-CoV-2 Omicron variant by sera from BNT162b2 or Coronavac vaccine recipients. Clin Infect Dis. $2021 \mathrm{Dec}$ 16;ciab1041. doi: 10.1093/cid/ciab1041. 


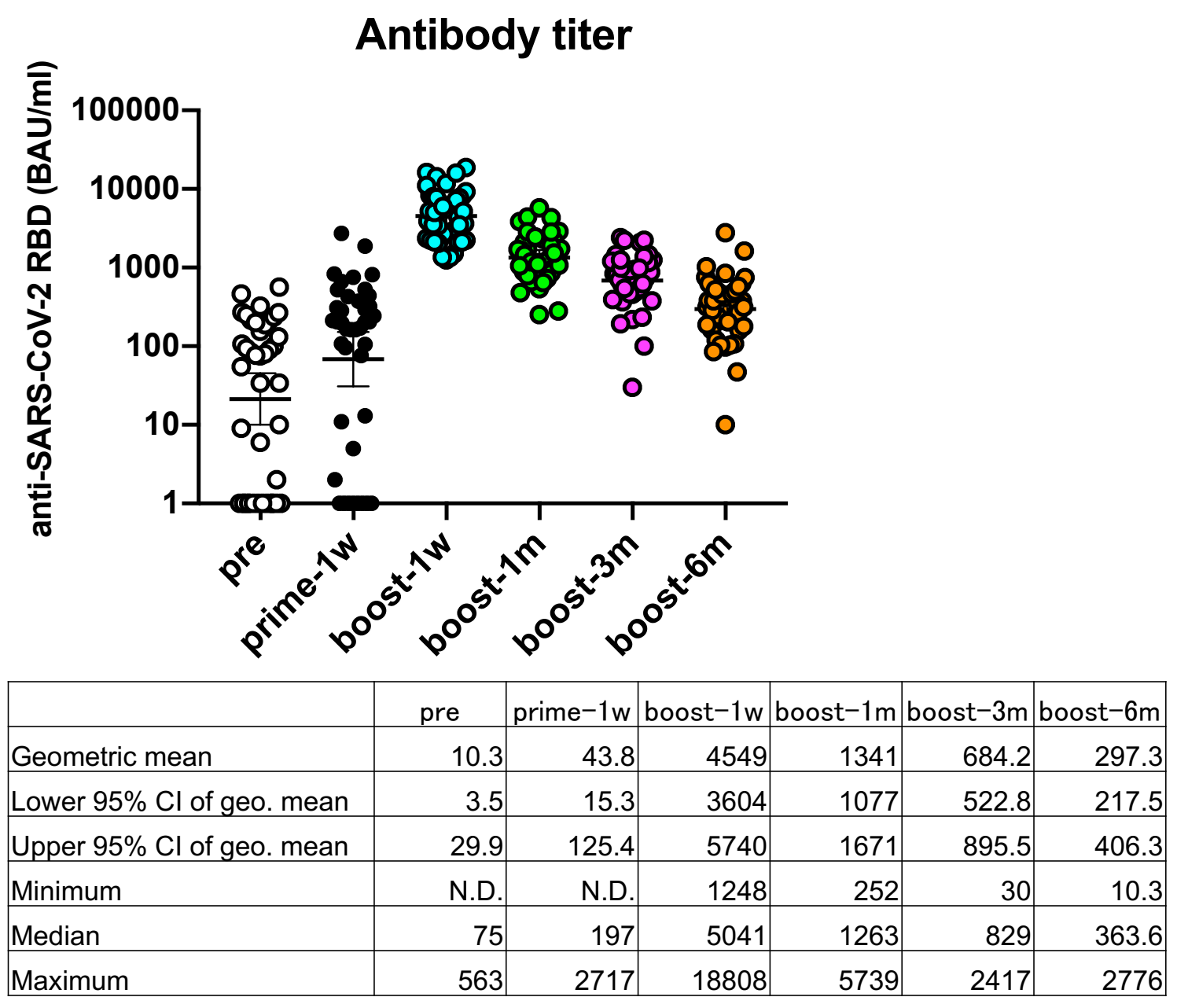

Figure 1. Transition of anti-SARS-CoV-2 responses after the COVID-19 mRNA BNT162b2/Pfizer vaccination

Responses to the COVID-19 mRNA vaccine were measured as anti-SARS-CoV-2 RBD IgG antibodies before the first vaccination (pre), 1 week after the first vaccination (prime$1 \mathrm{w}$ ), and 1 week (boost-1w), 1 month (boost-1m), 3 months (boost-3m), and 6 months (boost-6m) after the second vaccination ( $\mathrm{n}=41$ participants). N.D.= Not detectable. 


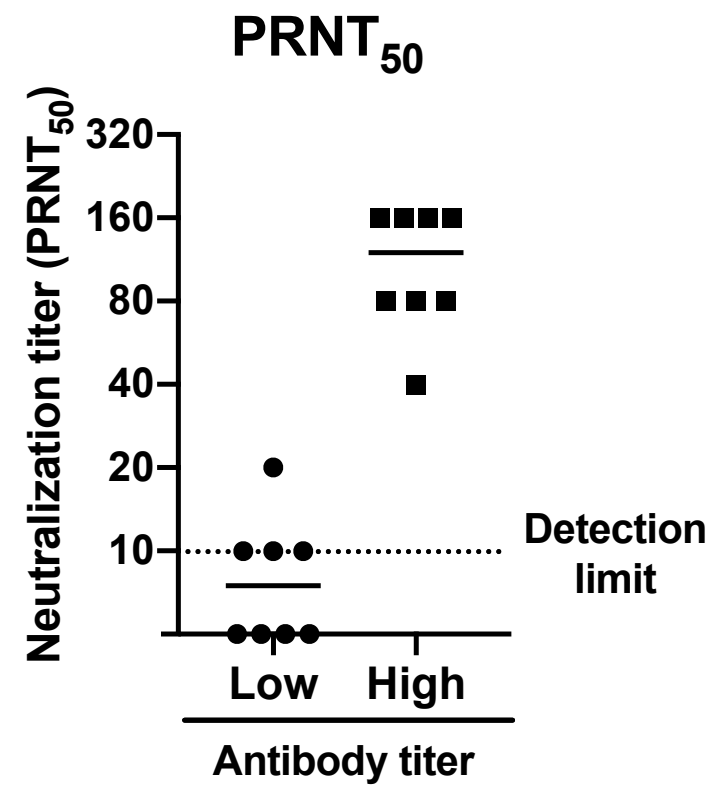

Figure 2. Distribution of the neutralizing antibody response 6 months after the COVID-19 mRNA booster

Neutralizing antibody levels from the eight highest and eight lowest anti-SARS-CoV-2 RBD antibody levels were measured via 50\% plaque-reduction neutralization test $\left(\mathrm{PRNT}_{50}\right)$ titers. 